https://doi.org/10.18485/kij.2019.66.1.8

ПРЕДРАГ Д. ДИЛПАРИЋ *

Универзитет у Београду

Филолошки факултет
Оригинални научни рад

Примљен: 15. 03. 2019.

Прихваћен: 24. 04. 2019.

\title{
МЕСНЕ ПРЕДЛОШКЕ КОНСТРУКЦИЈЕ У ДВЕ ХРИСОВУЉЕ КРАЉА СТЕФАНА УРОША І
}

\begin{abstract}
Рад се бави значењем и употребом месних предлошко-падешких конструкција у двема хрисовуљама краља Стефана Уроша I. Значење и употреба ових конструкција упоређена је са стањем у старословенским и српскословенским рукописима. Посебно је праћена појава употребе предлога и предлошко-падешких конструкција непознатих старословенским рукописима.
\end{abstract} росрпски.

Кључне речи: предлошко-падешке конструкције, семантика, српскословенски, ста-

1. О хрисовуљама у овом раду. Реч је, најпре, о Хрисовуљи краљь Стефрана Уроша I манастиру св. богородице у Стону, записаној око 1252. године, која се издаје уместо изгубљене повеље краља Стефана Првовенчаног овом старијем седишту хумског епископа. Поменутом обновљеном хрисовуљом краљ Урош I je, како се наводи, „хтео да уреди питање прихода стонске цркве, који су после метежа на тој страни и његова рата са Дубровником год. 1252-1254, свакако били поремећени" (Зборник 2011: 196). Друга хрисовуља која је овде испитивана јесте много обимнија од претходне Хрисовуља краља Стефана Уроша I манастиру св. апостола Петра и Павла на Лиму, настала између 1254-1263, највероватније око 1260. године (Зборник 2011: 225-226). Она је сачињена услед потребе за потврђивањем првобитно поклона хумског кнеза Мирослава манастиру Св. Петра и Павла на Лиму. Наведени поклон, наиме, обновљен је био хрисовуљом краља Стефана Првовенчаног коју су пак однели Бугари приликом војне кампање у Сpбији. Притом, наведени манастир постаје ново важно седиште хумске епархије

*dilparicp@gmail.com 
којем краљ Урош I властитом хрисовуљом потврђује имања и људе будући да су припадали претходном седишту у манастиру Св. богородице у Стону.

Однос између ових двеју хрисовуља и нарочито аутентичност ове млађе били су, као што је познато, предмет расправа у обимној медиевалистичкој литератури. Треба рећи, исто, да оригинали ових повеља нису сачувани, већ само њихови доцнији преписи. Осим тога, оригинал Хрисовуље краља Стефана Уроша I манастиру св. апостола Петра и Павла на Лиму вероватно је био сачуван у доба краља Стефана Уроша II Милутина. У његовој повељи истом манастиру, наиме, сачињеној између друге половине 1317. и 29.10.1321, датума краљеве смрти, идентификовани су делови текста тачније преписани са несачуваног оригинала него што је то случај у наведеној хрисовуљи краља Уроша I (Зборник 2011: 226).

2.Примери: значење и употреба. Примери месних предлошко-падешких конструкција које су предмет овог рада забележени у Хрисовуљи краљь Стефана Уроша I манастиру св. богородице у Стону биће у даљем тексту означени скраћеницом БС, док се они из Хрисовуље краља Стефана Уроша I манастиру св. апостола Петра и Павла на Лиму наводе под ознаком ППЛ. Поред тога, нису наведени сви забележени примери, већ само они који адекватније илуструју употребу ових конструкција, при чему је наведен њихов укупан број.

2.1.1. Два примера конструкција предлога около са генитивом БС zємлґ (юколо црьквє и ППЛ zємлд Фколо црквє истозначна су са старословенским и српскословенским конструкцијама окрьсть + генитив које имају значење предмета око кога се врши радња (Дилпарић 2018: 80-81; Ходова 1971: 49-50; ИСС 1963: 366; РС: 410; ССЯ II: 534). Реч је о релативно честим старословенским и српскословенским конструкцијама типа выстъ на вьсьхъ страхъ жнвхштннхъ окрсть нхъ. Конкурентске конструкције наведној генитивној представљају оне о + локатив, типа вндњвъ жє нсӓ многъ народъ о сєвъ, врло ретке нд + локатив жzы оБлєжАштА на Н̂ємъ, Уз глагол чија семантика подразумева окруживање неког предмета другим предметима, односно, окрхгъ + генитив, попут съдњахх окрхг тьлєсоү єю (Дилпарић 2018: 80-81; Ходова 1971: 50). Употреба последње конкурентне конструкције у старословенским споменицима сведочи, међутим, о тенденцији реинтерпрентирања њеног значења од „око, около” ка „у близини”, о чему сведоче и примери забележени у хрисовуљама које треба разумети у значењу „у близини”. Старославянский словарь (по рукописям X-XI веков) не бележи конструкције около + генитив, док их много обимнији Словарь старославянского языка наводи у засебној одредници, као што то чине и Даничићев Рјечник из књижевних старина српских и Рјечник JA3У (CCЯ II: 530; PCC II: 211; RJAZU VIII: 835).

2.1.2. Усамљени пример конструкције предлога прн са локативом ППЛ пры цєєю једнак је са старословенским и српскословенским конструкцијама прн + локатив које означавају близину у простору који није затворен (Дилпарић 2018: 250; Ходова 1971: 43). То су конструкције типа ндє прн морн галнльнстьщь са дериватима са значењском нијансом поседовања типа да єстъ прн іิєщь кадннци или онима са значењем „у нечијем присуству; пред неким” типа нжє отъвръжєТъ сА 
мєнє прн чловъцҺхъ (ИСС 1963: 354; Ходова 1971: 44). У српскословенским и старословенским споменицима конкурентне конструкције наведеној локативној представљају влнъъ + генитив (датив), типа влндъ въ ићсто града, нскръ + генитив, типа прндє жє нСъ въ Градъ [...] Іскръ вьсн ғжжє дастъ нБковъ носнфоү, или оү + генитив, типа стоћшє ог грова вьнь пхачхштн, али и оне са социјативном нијансом, типа оr тєБє сътворюх пасхх (Дилпарић 2018: 250-251; Ходова 1971: 44-47).

2.1.3. Предлог конь са генитивом: ППЛ сєло Аютнне конь мостач конь савнна сганокосау конь даданна полач конь потокач конь шыповє полане; (још 4х).

Старославянский словарь (по рукописям X-XI веков) и Словарь старославянского языка не бележе конструкције конь + генитив, док их Даничићев Рјечник из книюевних старина српских и Рјечник ЈАЗУ наводе у засебним одредницама (PCC I: 470; RJAZU V: 253). Последњи речник бележи и употребу од 14. века новијег предлога „код” са истим значењем близине, насталог по аналогији према „под, над пред”. Поред тога, понеки пример из млађе хрисовуље краља Уроша I вероватно се може пре разумети у сродном значењу слеђења у простору, тј. „што је за чим у простору” како бележи Рјечник JA3У (RJAZU VII: 400). Tо се односи пре свега на пример мєда ємю ... (.ть варьднща оү главыцю конь главыце оү лыпопопово Аастовь, још и више на примере врьтоломганню цркв, конь шыповє поланє по вргагю и оү гомылю н оү граныцю конь гомылє.

Исто што и за претходне примере се може рећи за усамљени пример конструкције предлога наконь са генитивом забележен у ППЛ наконь мада, будући да он значи што и конь + генитив (PCC I: 470; RJAZU VII: 400). Рјечник JАЗУ наводи, наиме, поред значења „покрај, поред, код”, значење „што је за чим у простору” које одговара управо наведеном примеру из млађе хрисовуље краља Уроша I.

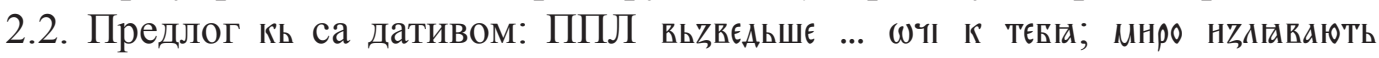
прнтюккаючниь Кь вамь; Кь дґвнчю потокю; кь арьБанашю потокю

Старословенске и српскословенске онструкције кь + датив овог типа означавају предмет у близини којег се налази завршна тачка, односно изиь ка којем је кретање усмерено (Дилпарић 2018: 97; Ходова 1971: 86-89). Према фреквенцији и према семантици глагола у њима ове конструкције се разврставају: а) кь + датив са глаголима кретања, тип ндє къ отцю своємоү, б) кь + датив са глаголима , покретања/премештања”,тип вєсл къ канњ $\phi$ њ, в) кь + датив са глаголима „,побуђивања на кретање”, тип съдњ къ вамъ (Дилпарић 2018: 97; Ходова 1971: 86-89).

Са друге стране, два примера конструкција предлога пръма са дативом ППЛ

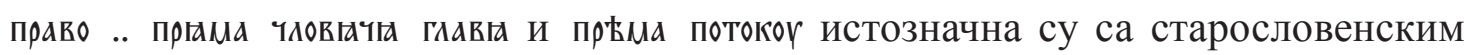
и српскословенским конструкцијама прьмо (прємо)/протнвоү + датив и означавају усмереност радње, тј. да се радња врши испред, насупрот или право пред ким или чим (Дилпарић 2018: 114; Ходова 1971: 53, 59-60; ИСС 1963: 366; РСС II: 494-495). Словарь старославянского языка наводи и примере конструкција пръмо + генитив у истом значењу, типа въвєдє адама н въєлн пръмо раъ (ССЯ III: 459). Примере последњег типа, међутим, испитиване хрисовуље не бележе. 
Рјечник $J A 3 У$ наводи месне конструкције прњма + датив, са варијантама прам/прама + датив, у значењима смера „камо је што управљено”, „обрнутог положаја некога или нечега к некоме или нечему" и места поред кога се нешто налази, али само у примерима између 14. и 17. столећа (RJAZU XI: 361-362, 595, 616). Овде наведени примери, међутим, потичу из шесте деценије 13. века.

2.3. Предлог оть са генитивом: БС сєло поннкьвн а мега мог ... (От стона; мега селог

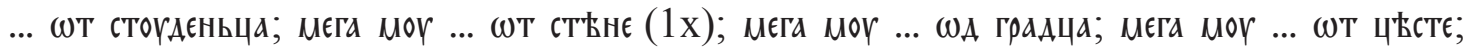

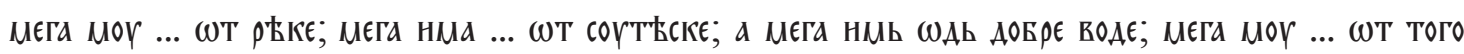

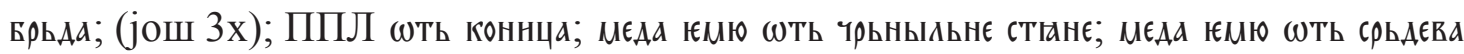
врьда; (бть кыпрьннка; (Тть цвБатоювнне; оть са генитивом у значењу „промена стања”: БС радоүн сє мостє прЊводє Фт смрьтн вь жнвоть

Конструкције оть + генитив овог типа у старословенским и српскословенским споменицима јављају се у значењу почетне тачке кретања, односно предмета у чијој близини или у чијим границама се налази почетна тачка кретања (Дилпарић 2018: 17-20; Ходова 1971: 103). Оне могу означавати и прелазак од/ из једног стања у неко друго и другачије стање или промену стања. Притом ове месне конструкције неретко смењују се у наведеним споменицима конструкцијама нъь + генитив, съ + генитив, or + генитив или слободним генитивом (Дилпарић 2018: 18-20; Ходова 1971: 105, 167; Ходова 1963: 69; ИСС 1963: 340). Поменуто варирање конструкција ове две хрисовуље краља Уроша I не бележе.

Супротно од претходно наведених конструкција, усамљени пример конструкције предлога до са генитивом, БС мєга єн ... до соүтТскє, одговара српскословенским и старословенским конструкцијама до + генитив које имају значење заврине тачке кретања, односно предмета са којим је у контакту та тачка (Дилпарић 2018: 46; Ходова 1971: 96-97; ИСС 1963: 358).

2.4.1. Предлог по са локативом: БС н по АҺлоү право надь вълог водог; а мега ниь

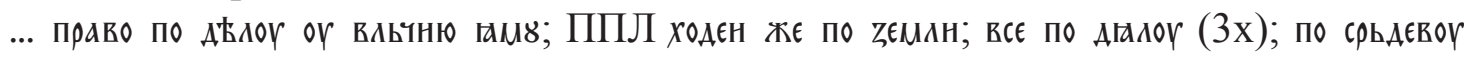
врьдоү; по Бргагю ргапьнога дола; (још 19х)

Забележене конструкције по + локатив овог типа одговарају српскословенским и старословенским конструкцијама по + датив и означавају простор у чијим границама је смештен пут кретаға организованог према једној линији (Дилпарић 2018: 103-104; Ходова 1971: 80; RJAZU X: 107-109). Уопштеније гледано, у најужем сродству су са конструкцијама које значе кретање са пуним укључивањем у предмет, типа по жнламъ, или са конструкцијама типа ндє по въсемог градоү са значењем распростирања радње (Дилпарић 2018: 104; Ходова 1971: 80-81; ИСС 1963: 333). Поред тога, није непознато да старословенски и српскословенски споменици бележе примере у којима се јавља, ређе или чешће, смењивање конструкција по + датив конструкцијама по + локатив са значењем пута кретања. Рјечник $J A 3 У$ наводи примере овог смењивања на старосрпскохрватском терену од 13. века (RJAZU X: 107-109). Узроци овог смењивања налазе ce, као што је познато, „у обличком једначењу датива и локатива, као и њиховој ресемантизацији и последичном преобликовању семантике конструкције по + 
датив/локатив које се састојало у губљењу значења правца кретања, усмерености и управљености ка предмету и развијању значења места - диференцирање започето најпре уз глаголе који означавају кретање јачег интензитета - што је све условило сразмерну и постепену експанзију локатива и његових предлошко-падешких конструкција" (Дилпарић 2018: 104; Ходова 1971: 82; ИСС 1963: 333; Топоров 1961: 294-301).

2.4.2. Предлог на са акузативом: БС сєло поннкьвн а мега моү ... на прнстаннщє;

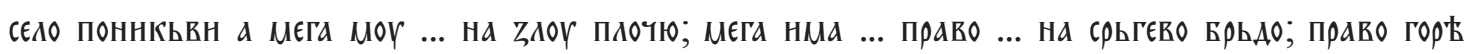

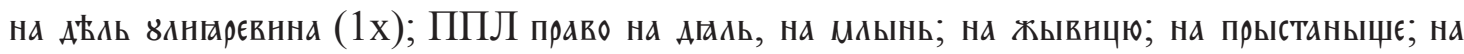

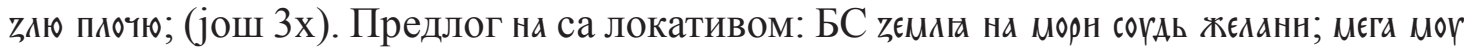

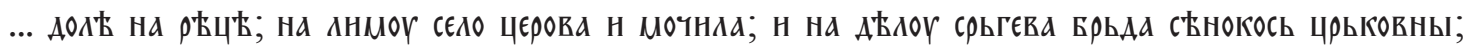

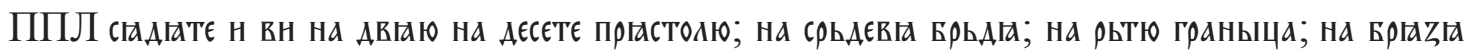

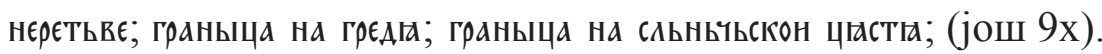

Старословенске и српскословенске конструкције на + акузатив означавају појам који непотпуно укључује крајњу тачку кретања тј. место завршетка кретања које се налази на горњој површини или на спољној страни различитих предмета (Дилпарић 2018: 130; Ходова 1971: 100; ИСС 1963: 326). Конструкције на + акузатив овог типа јављају се у писаним старословенским и редакцијским споменицима и са неким специфичнијим месним значењима: а) „отправления на какое-либо собрание и участия в нем", типа вћсл н на съьоръ, у конкуренцији са на + локатив, б) „направление к лииу”, типа прндє на савннж, у конкуренцији са кь + датив, в) „направление в страны света”, типа врьгъ нматъ на дападъ, у конкуренцији са вь + акузатив (ИСС 1963: 326, 327-328).

Поред тога, уз глаголе који имају значење кретања мале интензивности типа пастн, положнтн, потопнтн, състн, съБтн, поставнтн, варнтн и сл. у старословенским текстовима много чешће се употребљавају конструкције на + локатив (ИСС 1963: 328; Ходова 1971: 101). Реч је о познатој појави смењивања старословенских конструкција нд + акузатив конструкцијама на + локатив која је „у вези са динамичком или статичком перцепцијом, односно са потребом означавања усмерености на површину, тип вьzндє на горх, или са потребом означавања положаја на површини/резултата кретања, тип съдАштю жє ємоү на схднштн” (Дилпарић 2018: 131).

Са друге стране, конструкције на + локатив означавају појам ка коме је усмерено кретање и који због своје природе не допушта потпуно укључивање завршне тачке кретана (Дилпарић 2018: 225; Ходова 1971: 65, 67; ИСС 1963: 326328). Понекад се ове старословенске и српскословенске конструкције смењују, поред на + акузатив, са конструкцијама о (ов) + акузатив или са конструкцијама прн + локатив (Дилпарић 2018: 225, 227; Ходова 1971: 67, 69).

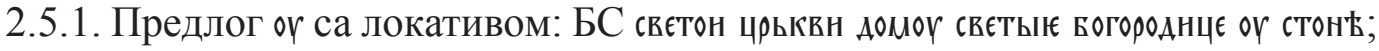

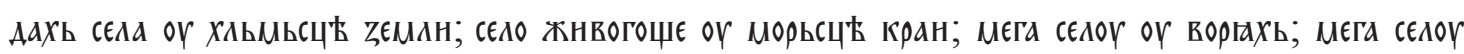

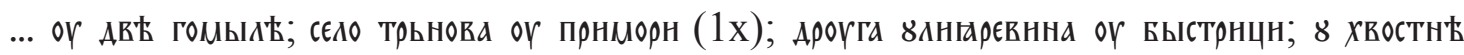

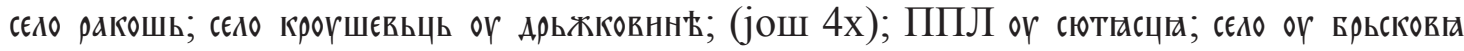

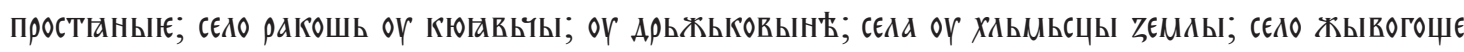


ог морьсціа кран; оү стонга (1x), ог трьнон горг. Предлог ог са акузативом: БС поннкьвн

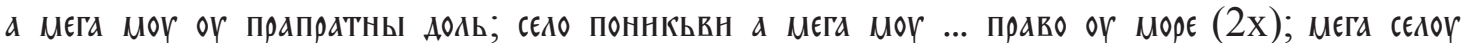

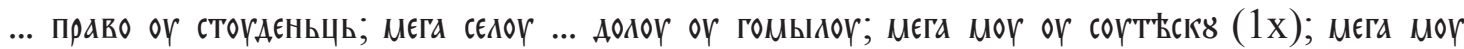

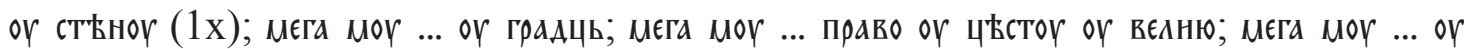
Планнног; а мега нМь ... Право ... оү мнхолю црьквь; оү оүнчнньскы потокь; како оүпада оү

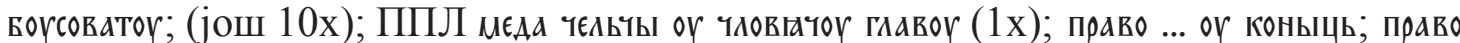

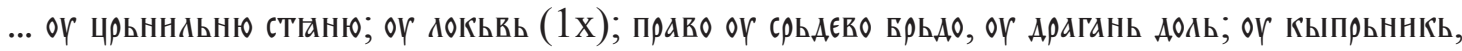

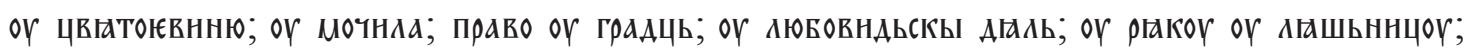

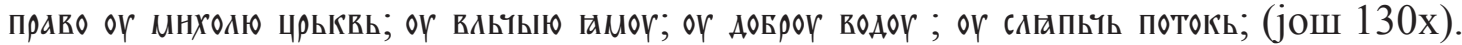
Предлог вь са локативом: ППЛ сн вь ғарғахь; сющаға вь мнрға; вюрюющнхь словєсєМь нХь

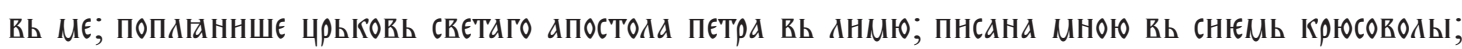
Фтьцць вь ныкєн. Предлог вь са акузативом: ППЛ ндн вь єєнкен; БС радоүн сє мостє ПрБвоАЕ

Конструкције or + локатив одговарају старословенским и српскословенским конструкцијама вь + локатив које имају значење затвореног простора у који се потпуно укључује неки предмет (Дилпарић 2018: 207; Ходова 1971: 61). Унутрашњост затвореног простора неретко се разуме као целовита или „као издељена (нешто се може налазити или се нека радња може вршити међу деловима нечега)", при чему простор може представљати и подручје осећања, мишљења и доживљавања (Дилпарић 2018: 207; Ходова 1971: 62-63, 65; ИСС 1963: 320). Месне конструкције оү/вь + локатив представљају „статическую противо положность аккузативных сочетаний" и чешће су уз глаголе који означавају кретање мање интензивности, типа положнтн, сњатн, омочнтн, поставнтн, погрхzнтн, пастн, състн, оүправнтн и сл. (ИСС 1963: 273, 320-32; Ходова 1971: 63-64). Сведочанство о новијој појави наглашавања дејства као процеса, оү/вь + акузатив, насупрот старијем наглашавању резултата дејства (стања), oү/вь + локатив, представљају, међутим, релативно чести старословенски и српскословенски примери смењивања попут падъшєн въ тръннн насупрот новијем и све учесталијем падъшєн въ трьньє (ИСС 1963: 273; Ходова 1971: 63-64; Дилпарић 2018: 209-211).

Конструкције оү/вь + акузатив, са друге стране, означавају појам који nоmпуно укључује крајњу тачку кретања у простору који може бити схваћен и апстрактно као подручје осећања, мишљења и доживљавања обухватајући притом и „семантику усмерености међу више предмета, али и место додира уз одговарајуће глаголе: у првом случају конструкција вь + акузатив аналогна је конструкцијама мєждог + акузатив (инструментал), док је у другом реч о конструкцијама са глаголима типа коснхтн, оүдарнтн, костн, потъкнжтн и сл." (Дилпарић 2018: 117, 119-120; Ходова 1971: 86, 98; ИСС 1963: 318-319, 365).

2.5.2. Усамљени пример конструкције предлога мєдю са инструменталом ППЛ мєдю казома јавља се $у$ значењу положаја у средини међу више предмета (Дилпарић 2018: 202-204; Ходова 1971: 71; ИСС 1963: 365). Треба рећи да као и у старословенским и српскословенским споменицима (са предлогом мєждог) истоврсни предмети се употребљавају обавезно у множини или у двојини, као у наведном примеру преузетом из ППЛ (Дилпарић 2018: 202; Ходова 1971: 71-72). 
Усамљени пример сложеног предлога по ср\$дњ са генитивом ППЛ право по

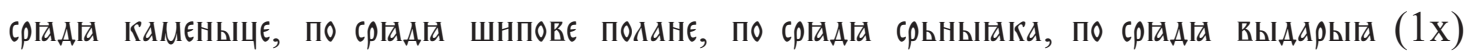
има значење завршне тачке кретања која се налази у иеентру (Дилпарић 2018: 81-82; Ходова 1971: 102). Ове конструкције познате су и старословенским и редакцијским споменицима.

2.6. Два примера конструкције предлога надь са акузативом БС мєга нма ... Право надь Бьлоү водоү и мега моү ... над сасє јављају се $у$ значеңу предмета изнад кога се налази завршна тачка кретања (Дилпарић 2018: 168; Ходова 1971: 92). Познате су и старословенским и редакцијским споменицима, као што је познато и њихово смењивање са различитим конструкцијама (Дилпарић 2018: 169-170).

Блиски по значењу претходним примерима су примери конструкције предлога вышє са генитивом БС мєга нма вышє моста, ППЛ мєда єею вншє моста, вншє Борошєвннє, вншє скочнгорннє вышє Быстрьца и још три остала познају и старословенски споменици (РС: 161; ССЯ I: 361; РСС I: 194). Јављају се у значењу положаја изнад, на горњој површини, као и конструкције врьхог + генитив, много чешће у старословенским споменицима од претходних (Дилпарић 2018: 66-67; Ходова 1971: 78; ИСС 1963: 366).

Претходним двема групама примера припадају и ови са сложеним предлогом овь врьхь са генитивом БС ФБрьхь выстрьцє двњ пєкн црковнЊ и ППЛ ФБрьхь выстрьца који бележе конструкције у месном значењу изнад, поврх нечега (Дилпарић 2018: 66; Ходова 1971: 78; ССЯ I : 226; ССЯ II : 460; RJAZU VIII : 461). Рјечник из књижевних старина српских бележи само варијанту оврьхь + генитив (PCC II : 191).

Насупрот наведеним примерима стоје два примера конструкције предлога под са инструменталом БС дроүга длннаєвннна ... ПоА планнном и ППЛ Подь дюБома која имају значење предмета испод којег се нешто налази или се нешто врши (Дилпарић 2018: 196; Ходова 1971: 58). Ове конструкције познате су и старословенским и редакцијским споменицима, као што су познате и њихове паралеле, акузативне конструкције са истим предлогом у значењу динамичке перцепције.

Коначно, групи примера са значењима положаја изнад могу се придружити и конструкције прьz + акузатив означавају место/кретање изнад или поврх нечега (RJAZU XI: 810; PCC II: 490). Старославянский словарь (по рукописям $X-X I$ веков) не бележи ове месне конструкције, за разлику од његовог обимнијег прототипа Словаря старославянского языка (CCЯ IV: 440). Реч је о следећим примерима: БС сєло поннкьвн а мега моү ... прьz врьдо (3х); мега моү ... право прьz рькоү; ППЛ прґазь потокь (1х); прназь выстрьць; прназь рғакоү прґзь тароү; (још 10х). Осим тога, конструкције са предлогом прько и генитивом, забележене у два примера ППЛ прғко Бдчнна дола и прњко потока, имају исто значење као прьz + акузатив (RJAZU XI: 551; PCC II: 492-493). Међутим, старословенски рукописи их не познају, судећи по томе што их поменути старословенски речници не наводе, док их Pjeчник $J A 3 У$ наводи у примерима из 14 . и 15 . столећа. 
2.7. Предлог оүзь са акузативом: БС сєло поннгкьвн а мега мог ... н горь оүz Брьдо

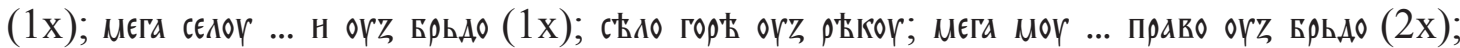
ППЛ право оүзь дґаль (1х); оүсь потокь (2x); право оүзь Брьдо (1x); ( још 7х).

Примери конструкција оүzь + акузатив уопштено гледано одговарају старословенским и српскословенским примерима са месним значењем близине или протезања уздужно или кретаға ка горњој повриини (ССЯ I: 246; РСС I: 176; RJAZU XX: 223-225). Притом, Рјечник JA3У наводи као најстарију потврду употребе конструкција оүzь + акузатив са значењем „дуж, уздуж” један пример из рукописа насталог у доба краља Стефана Уроша II Милутина. Поменуто значење овде илуструју примери типа оүсь потокь; оне са значењем близине представља съ九о горь oүz рькоү, док кретање ка горњој површини они типа мєга сєлоү ... н Оүз Брьдо и Право оүZь Аґаль.

Супротно од наведених, неколико примера конструкција предлога ннz са акузативом означавају место којим се нешто креће или протеже надоле (RJAZU VIII: 204-205; РCC II: 157). Реч је о примерима БС н ннд Брьдо доль; мега єен ннz рькоү и ППЛ право нызь дґаль; право нндь потокь; ныс саґпьть потокь; (још 4х). Старословенски речници консултовани у овом раду не бележе употребу ових конструкција, него само употребу прилога ннzь у примерима попут нсоүсь жє ннzь полкионь сл (ССЯ II: 424; РС: 379).

2.8. Усамљени пример конструкције предлога ов са акузативом БС н страног јавља се у значену непотпуно обухваћеног места, тј. око, са свих страна (Дилпарић 2018: 151, 153-154; Ходова 1971: 67; ИСС 1963: 344). Она се може, међутим, такође посматрати и као део предлошког израза са генитивом, као што је то случај у примерима конструкција ов сню страноү + генитив, БС мега моү ФБь сню

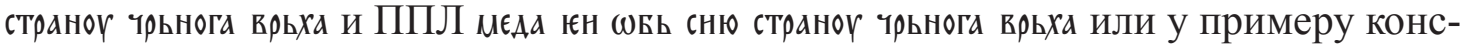
трукције ов оноү страноү + генитив ППЛ мега хомодю Обе конструкције познате су и старословенским и редакцијским споменицима. Осим тога, близак по значењу наведеним је усамљени пример конструкције предлога сь са генитивом ППЛ сь южьнє странє јавља се у значењу почетне тачке која се налази на спољној страни нечега (Дилпарић 2018: 52; Ходова 1971: 106; ИСС 1963: 341). Конструкције овог типа исто су познате старословенским и редакцијским рукописима.

Коначно, широј групи примера са значењем непотпуно обухваћеног простора могу се условно прикључити и три примера конструкције предлога za + акузатив: БС мєга моү ... zа лопатог, ППЛ zа єлғаноү главоү и zа вєлыє полє. Оне означавају предмет иза којег се налази завршна тачка ка којој је кретање усмерено (Дилпарић 2018: 156; Ходова 1971: 91; ИСС 1963: 355-356). Поменуте акузативне конструкције познате су старословенским и редакцијским рукописима. По истом критеријуму се конструкције мымо + акузатив које се јављају у усамљеном примеру ППЛ мымо гомылю у значењу кретања ,нечему са стране” такође могу прикључити овој групи (RJAZU VI: 707; PCC II: 71). Старословенски рукописи, међутим, не бележе ове конструкције. 
3. Новије језичке црте. Посматрано из старословенске перспективе, најпpe, новину у испитиваним хрисовуљама представља употреба конструкција конь/ наконь/прько + генитив и ннz/мымо + акузатив које овде коришћени старословенски речници не наводе. Поред тога, конструкцију около + генитив, како је такође наведено, бележи само Словарь старославянского языка. Релативна новина је употреба конструкције по + локатив уместо старије по + датив, што је забележено спорадично и у старословенским текстовима. Јављање архаичних словенских конструкција вь + локатив/акузатив у почетним и завршним редовима обеју хрисовуља није, међутим, непознато ни српским рукописима. С обзиром на обим хрисовуља, богатије варирање различитих међусобно конкурентних конструкција познато старословенским и уопште српским редакцијским текстовима очекивано није забележено.

Са друге стране, Рјечник JAЗУ наводи, како је речено, употребу месних конструкција прњма + датив у примерима од 14. века надаље, али примери из млађе хрисовуље краља Уроша I потичу са краја шесте деценије 13. века. Слично овом, конструкције прько + генитив наводи само у примерима из 14. и 15. столећа, али одговарајуће примере исто бележи млађа хрисовуља. Међутим, употребу конструкција конь/наконь + генитив које такође бележи млађа хрисовуља наведени речник не датира, али посредно потврђује њихову ранију употребу будући да бележи да се смењују новијим конструкцијама код + генитив од 14. века. Коначно, исти речник употребу конструкција ннz/мымо + акузатив потврђује примерима из 13. века, као што то чине и испитиване хрисовуље.

\section{ЛИТЕРАТУРА}

Дилпарић 2018: Предраг Д. Дилпарић, Предлошко-падежне конструкиије у српским тетракосима 13. и 14. века, Београд: Филолошки факултет, Чигоја штампа.

Зборник 2011: Зборник средњовековних ћириличких повеља и писама Србије, Босне и Дубровника, књ. I, Београд: Историјски институт Београд.

ИСС 1963: Исследования по синтаксису старославянского языка. Сборник cmameй, [ред. Ј. Курц], Прага: Издательство Чехословацкой академии наук.

СТБЛГ 1993: Граматика на старобългарския език, София: Българския академия на науките.

Топоров 1961: В. Н. Топоров, Локатив в славянских языках, Москва: АН СССР.

Ходова 1963: К. И. Ходова, Система падежей старославянского языка, Москва: Издательство АН СССР.

Ходова 1971: К. И. Ходова, Падежи с предлогами в старославянском языке, Москва: Издательство Наука. 
RJAZU: Rječnik hrvatskoga ili srpskoga jezika, Zagreb: Jugoslavenska akademija znanosti i umjetnosti, 1880/1882 - 1975/1976.

PCC: Ђ. Даничић, Рјечник из књижевних старина српских (том 1-3), Београд: Вук Караџић, 1975.

PC: Старославянский словарь (по рукописям X-XI веков), [под редакцией Р. М. Цейтлин, Р. Вечерки и Е. Благовой], Москва: Русскый язык, 1994.

ССЯ: Словарь старославянского языка (репринтное издание), том 1-4, [Чешкая Академия наук, 1966-1997], Санкт-Петербург: Издательство Санкт-Петербургского университета, 2006.

Predrag D. Dilparić

\section{PLACE CONSTRUCTIONS IN TWO MUNIMENTS OF THE KING STEFAN UROŠ I}

Summary

The paper deals with the meaning and the use of meat pre-construction structures in the two not yet examined chapters of King Stefan Uros I. The meaning and use of these structures is compared with the situation in Old Slavic and Serbian manuscripts. Particularly observed is the occurrence of the use of templates and pre-construction structures of unknown Old-Slavic manuscripts. 